\title{
The Seeds of The Commons: Peer-to-Peer Alternatives for Planetary Survival and Justice
}

\author{
Michel Bauwens ${ }^{1} \cdot$ Petar Jandrić ${ }^{2,3}$
}

Accepted: 27 January 2021 / Published online: 9 March 2021

(c) The Author(s), under exclusive licence to Springer Nature Switzerland AG part of Springer Nature 2021

Keywords Peer-to-peer · Postdigital · P2P · Commons · Capitalism · History · Religion · Transhumanism · Seed forms · Blockchain · Bitcoin · Cosmo-local · P2P accounting $\cdot$ Market $\cdot$ Michel Bauwens $\cdot$ Peer-to-peer Foundation

\section{Introduction}

Michel Bauwens ${ }^{1}$ is the founder of the Foundation for Peer-to-Peer Alternatives ${ }^{2}$ and works in collaboration with a global group of researchers in the exploration of peer production, governance, and property. He co-produced the 3-hour TV documentary TechnoCalyps with Frank Theys (2006) and co-edited the two-volume book on anthropology of digital society with Salvino Salvaggio. With Jean Lievens, he published a best-selling interview transcript 'De Wereld Redden, met peer to peer naar een post-kapitalistische samenleving' (Bauwens and Lievens 2013). With Vasilis Kostakis, he published the book Network Society and Future Scenarios for a Collaborative Economy (Kostakis and Bauwens 2014). His latest publication, with Alex Pazaitis, is 'P2P Accounting for Planetary Survival Towards a P2P Infrastructure for a Socially-Just Circular Society' (Bauwens and Pazaitis 2020). He has written editorials for Al Jazeera English and other media outlets. He is listed at \#82, on the Post Growth Institute (En)Rich list. ${ }^{3}$

\footnotetext{
1 This biographical note is reworked from https://wiki.p2pfoundation.net/Michel_Bauwens/Full_Bio. Accessed 2 December 2020.

2 See https://p2pfoundation.net/. Accessed 2 December 2020.

3 See http://enrichlist.org/the-list/. Accessed 2 December 2020.

Petar Jandrić

pjandric@tvz.hr

Michel Bauwens

michel@p2pfoundation.net

1 Foundation for Peer-To-Peer Alternatives, Ghent, Belgium

2 Zagreb University of Applied Sciences, Zagreb, Croatia

3 University of Wolverhampton, Wolverhampton, UK
} 
In his first career, Michel worked for USIA, British Petroleum, Riverland Publications, Belgacom, and created two Internet start-ups on intranet/extranets (E-Com) and interactive marketing (KyberCo), which were sold to Alcatel and Tagora Holdings. After he switched career to P2P, Michel was Primavera Research Fellow at the University of Amsterdam and external expert at the Pontifical Academy of Social Sciences $(2008,2012)$. In 2014 Michel was the research director of the governmental transition project towards the social knowledge economy in Ecuador. ${ }^{4}$ In 2016 Michel was Honorary Fellow/Visiting Scholar with the Havens Center at UW-Madison, as an 'activist in resident' funded by the Link Foundation, to produce a major rewrite of P2P and Human Evolution (Bauwens 2005). In 2017 Bauwens advised the city of Ghent with a Commons Transition Plan. Until June 2020, he was advisor to the CEO of the European 'labour mutual' SMART.coop. Michel has taught at Payap University and Dhurakij Pandit University's International College, as well as IBICT, Rio de Janeiro.

Michel is adviser to the Board of the Union of International Associations (Brussels), advisor to Ouishare (Paris), Shareable magazine (San Francisco), and ShareLex. He is also scientific advisor to the Association Les Rencontres du MontBlanc, Forum International des Dirigeants de l'Economie Sociale et Solidaire (2013-), and Advisory Board member for the Fourth International Conference on Degrowth for Ecological Sustainability and Social Equity. He was the Chair of the Technology/ICT working group, Hangwa Forum (Beijing, Sichuan), which developed economic policies for long-term resilience including distributed manufacturing. He is a founding member of the Commons Strategies Group, with Silke Helfrich and David Bollier.

\section{About the Conversation}

Michel Bauwens and Petar Jandrić met through Michael Peters during production of Knowledge Socialism. The Rise of Peer Production: Collegiality, Collaboration, and Collective Intelligence (Peters et al. 2020). As we discovered our many common interests, we entered into a postdigital dialogue (Jandrić et al. 2019) consisting of numerous email exchanges through October 2020 to February 2021, and a 3-hour online conversation conducted on 2 November 2020. This article distils the main themes covered in our extensive discussions.

\section{The Uncertain Road to Commoning}

Petar Jandrić (PJ): What is Peer-to-Peer (P2P)?

Michel Bauwens (MB): P2P is a relational dynamic that allows any individual in the world to connect to any other individual through digital networking in order to self-organize or create new value streams. P2P is not just about communications, it is

\footnotetext{
${ }^{4}$ See https://floksociety.org/ and http://commonstransition.org/. Accessed 2 December 2020.
} 
about the capacity to organize beyond the physical level, and the open collaborative systems that allow such organization. We are no longer in a world of competing and closed entities; we now have ecosystems, where people can come in and out, and contribute or not. Commons are a shared resource that is produced, maintained, and protected by a community or a group of stakeholders, using their own norms and regulations. A lot of today's work with the $\mathrm{P} 2 \mathrm{P}$ dynamics is related to productive Commons.

PJ: What inspired you to start working with P2P?

MB: Before 2002, I was working in Internet start-ups and web consultancies. My last job, for a large Telecom, involved futures forecasting and scenario planning. This was in the late 1990s, the era of the globally networked anti-globalization movements, and the Zapatistas ${ }^{5}$ who organized their international solidarity from the forest with their computers. People such as Antonio Negri and others have started to write about $\mathrm{P} 2 \mathrm{P}$ as an emerging relational dynamic.

I was quite unhappy in the last years of my work. I had seen the world's problems getting worse, and had felt that I was a part of the problem rather than part of the solution. I could not be a Marxist like I was in my twenties, yet how could I change the world? I had the intuition that the P2P dynamic was equivalent to the printing revolution in the fifteenth century, not in a technologically determinist way, but in a more generic sense. The question I was seeking an answer to was: How will it change society and human relationships?

PJ: How did you bring this intuition into practice?

MB: In October 2002, I took a 2-year sabbatical to study social transformations and historical phase transitions. How did the Roman economic system transform into feudalism? How did feudalism become capitalism? These are, of course, traditional Marxist themes, but I wanted a fresh look. I arrived at the importance of seed forms - new patterns that carry a new social logic, that may create subsystems, that may develop into systems, and eventually become new social norms. For example, it took four centuries for capitalism to emerge from feudalism. During this period people invented the printing press, purgatory, double-entry book accounting, and many other seed forms. Yet, it is only when the bourgeoisie was strong enough to say, 'feudalism is not letting us work in ways we want, and we want a new form of society', that these seed forms came together to stir real social change from feudalism to capitalism.

PJ: So you don't believe in revolutions?

MB: I do not dismiss revolutions, but I believe that seed forms come first. Also, revolutions can take many different forms and do not necessarily follow the Marxist image shaped by the French and the Russian revolutions. The UK had a religious civil war in the sixteenth century, Prussia was transformed by its military class... There are so many examples that do not fit with the Marxist narrative. Revolutions are organic processes that cannot be anticipated. So, instead of trying to anticipate

\footnotetext{
5 The Zapatista Army of National Liberation is a far-left Mexican indigenous revolutionary group based in Chiapas, Mexico, and formed in 1994.
} 
what cannot be anticipated, I find it more productive to focus on these new patterns or the seeds of new forms of civilisation.

PJ: How did you put these ideas in practice?

MB: I started the P2P Wiki, ${ }^{6}$ and soon after, in November 2005, I received my first invitation to give a lecture on the Commons in Budapest. This work has gradually attracted more and more people, and a group of us wanted to create something more stable. In 2012, we founded the P2P Foundation. We worked in relative obscurity until 2014, when we were invited to do a commons transition project for the Ecuadorian government and people started taking us more seriously. We see ourselves as a 'hybrid organized network' (see Lovink and Rossiter 2018), a knowledge commons, where we 'peer produce knowledge about peer production'.

PJ: Capitalism has an amazing ability to appropriate its own alternatives (see Dean et al. 2019). Your work with Vasilis Kostakis on peer production of free software and open hardware exhibits a disturbing dynamic: the more 'communist' the sharing license, the more capitalist the practice (Bauwens and Kostakis 2014). How do you negotiate this dynamic between commoning and capitalism?

MB: Feudalism was based on productivity of the land. Also, it was an ethical system that extended beyond property: a relationship between the lord and the subjects included a set of non-proprietary rights and obligations. In the eleventh century, the merchant guilds started working with money. In order to survive, feudal lords had to become capitalists by renting out their land to investors from the emerging 'gentry'. Capitalism changed the feudal system from inside out. So how can commoners change capitalism in the same way?

Situated within capitalism, the commons bring about a new value regime. Marx claimed that surplus value comes from exploiting the labour force; Proudhon argued that surplus value comes from scaling up cooperation. These days we move from Marxist capitalism, where companies hire workers and then get the surplus value, to a Proudhonian capitalism, where citizen cooperation is the source of productivity. This is the business model of Uber, Airbnb, Google, Facebook, and others - they bring us together, and then they extract surplus value from our cooperation. They do not hire us, and our surplus value is not attached to our time at a workplace. Instead, they extract value from the free exchange and communication between workers. This is how the commons are currently co-opted within the capitalist system.

We need to think about reverse co-optation. How are we going to use the market, and the state, in ways that generate value for the commons and commoners? Capitalism is a translation of commons into capital; we need to translate capital into commons. We call this process 'transvestment' because it transforms one form of value into another. My work pragmatically examines what the communities are doing to achieve this.

PJ: These days, a popular way of dealing with the dynamic between commoning and capitalism is blockchain technology (Ralston 2019).

MB: Blockchain people have created a system based on community and open source, where they see themselves most often as little capitalists who identify with

${ }^{6}$ See https://wiki.p2pfoundation.net/P2P_Wiki. Accessed 20 December 2020. 
libertarianism. Yet, they do not live from capital - they live from their work as coders, developers, and so on. These workers are essential to the technical reproduction of capitalism, are highly skilled, and that gives them a vital role in the current system. That makes them a labour aristocracy of well-paid technical workers. For example, tokenization opens up funding to everyone. Banks and venture capitalists can buy tokens or micro shares, but they cannot dominate the marketplace, because they do not have any power over the ecosystem. Blockchain is maintained by people who want to work open source and make a living. Classical open source implies a lot of unpaid work, so blockchain is a form of class struggle where workers looking out for their own interests have found a way to hack the capitalist system.

The bitcoin, which is designed as a commodity currency, works entirely within the capitalist framework. It may even overtake gold as a primary reserve value! Hedge funders and banks are buying bitcoins, and this feeds the bitcoin community. So I believe that we are moving towards a post-capitalist system that will still have markets, but can be called social-ist as Erik Olin Wright defined it: a society defined by its social priorities, not by the private for-profit goals of exclusive owners. Here in Chiang Mai, Thailand, we have 25,000 developers and remote workers who fund themselves and their projects in this way. So what does this have to do with the commons? Blockchain is a commons, bitcoin code is a commons, and there is an enormous amount of community dynamic. It is a capitalist system, but not a corporate system - it is a system based on contributions. I don't think that blockchain is the answer, but it is one of the things that emerges out of the drive for increasing people's autonomy, for securing livelihoods, and hacking the system to enable that.

PJ: And what about less technological alternatives?

MB: There are many emerging types of post-corporate entities. Enspiral, which is a New Zealand based co-operative, ${ }^{7}$ consists of circa 40 different social entrepreneurs working on different projects. When they get external investment money, they keep it apart from their internal structure. For instance, they received a one-million-dollar investment for their open source decision-making system Loomio, ${ }^{8}$ and the investor did not have any direct power over its expenditure. In this way, they protect their mission-driven, purpose-driven entity against capital. Developed by Dmitry Kleiner (2010), the idea of transvestment captures the idea of using capital to develop commons and finding market mechanisms to maintain commons.

I do not have the recipe for the social transformation to commoning, just as fifteenth century people living in feudalism did not have a recipe for getting to eighteenth century capitalism. People continuously adapt to their situation, and I observe these adaptations.

PJ: Does that mean that your work aims at reaching beyond ideology? Does it even matter whether commoning will lead towards a socialist or capitalist future?

MB: We need to distinguish the market from capital. Capitalism is a particular kind of market, geared towards capital accumulation that does not take into account any externalities. But there are many other forms of market. For instance, generative markets, such as those researched by the Radical Xchange project, ${ }^{9}$ use market

\footnotetext{
7 See https://enspiral.com/. Accessed 2 December 2020.

${ }^{8}$ See https://www.loomio.org/. Accessed 2 December 2020.

9 See https://www.radicalxchange.org/. Accessed 18 January 2021.
} 
mechanisms for social equity. In the Middle Ages, markets were formed by workers' associations or the guilds - and that worked pretty well.

In that sense, my work is not ideological. I just examine what happens and whether it works or not. I don't want to make the common mistake of the Left and wait for the Big Bang that will change everything. I am looking at seed forms, which will develop into subsystems and then into larger systems, which will eventually bring about large-scale conflict between different social logics. But we are not there yet.

\section{Commoning for Planetary Survival and Regeneration}

PJ: You recently published a report 'P2P Accounting for Planetary Survival: Towards a P2P Infrastructure for a Socially-Just Circular Society' (Bauwens and Pazaitis 2020). What is $\mathrm{P} 2 \mathrm{P}$ accounting and how does it differ from traditional accounting?

MB: In the 1930s, there was this big debate between socialists and liberals called the 'Socialist Calculation Debate'. On the one side, were Friedrich Hayek, Joseph Schumpeter, Ludwig von Mises, and others, who argued that centralised planning could not work. On the opposite side, were Karl Polanyi, and others, who claimed that socialist planning could work (and in ways superior to capitalism). For almost one century it seemed that the leftists had lost the socialist calculation debate. These days, however, things are changing.

There are three main levels of resource allocation. (1) We have the state, which represents planning - either full planning as in Soviet times, or regulatory planning, as in the capitalist system. (2) We have market pricing, which regulates the allocation of capital. (3) Finally, we have the emergence of mutual coordination or 'stigmergy', which brings open source commoning into the picture.

Our proposal, 'P2P Accounting for Planetary Survival: Towards a P2P Infrastructure for a Socially-Just Circular Society' (Bauwens and Pazaitis 2020), consists of an integrated vision that combines the three forms, with mutual coordination at the first level. We now have distributed ledgers ${ }^{10}$ so that we can move from sharing code and knowledge to sharing transaction data, shared accounting, shared logistics, and so on. We are moving from the Internet of Communications to the Internet of Transactions which enables the development of collaborative open ecosystems consisting of networks of producers. I think this is a very important shift.

\footnotetext{
10 'A distributed ledger is a type of database that is shared, replicated, and synchronized among the members of a decentralized network. The distributed ledger records the transactions, such as the exchange of assets or data, among the participants in the network.Participants in the network govern and agree by consensus on the updates to the records in the ledger. No central authority or third-party mediator, such as a financial institution or clearinghouse, is involved. Every record in the distributed ledger has a timestamp and unique cryptographic signature, thus making the ledger an auditable, immutable history of all transactions in the network.' (IBM 2019) (Emphasis in the original.).
} 
PJ: And what about thermodynamic accounting?

MB: Thermodynamic accounting is the ability to see flows of matter and energy and have them integrated into your accounting system. This implies that we can create our own data commons, data trusts, data co-ops, and so on.

PJ: This is bound to be based on heaps of potentially sensitive data!

MB: Open collaborative ecosystems need a lot of data, but the problem is not with the data - the problem is who owns this data, and how they expropriate this data from the communities and individuals. At the moment, we are divested of our data all the way down to our desires and nervous systems. But if we switch to an attitude - 'okay, we collected this data and now we need to decide how to share it in the best interest of our community' - that fundamentally changes the debate.

PJ: Your report speaks of 'P2P Accounting for Planetary Survival' (Bauwens and Pazaitis 2020); with Jose Ramos, you are now preparing a Postdigital Science and Education commentary titled 'Placing the Commons in a Temporal Framework: The Commons as Planetary Regeneration Mechanism'. How can the commons enable planetary survival and regeneration?

MB: This is based on the Wave Pulse theories of human history. The theoretical background of the Wave Pulse theory emanates from Karl Polanyi and his double movement theory (1944/2001), Peter Turchin's cliodynamics ${ }^{11}$ and his Seshat database, ${ }^{12}$ and so on. Wave Pulse theories emerged from various sources, yet they all agree that human civilisation is related to biophysical realities, and that class societies have a tendency to grow beyond their capacity.

'Wave Pulse theories are cyclical theories of human history, which see societies evolving in a succession between more extractive/degradative phases, and more regenerative phases in which the commons operate as a key "healing" mechanism. ${ }^{13}$ During the degradative phases of consumptive expansion, the ruling class pushes towards the use of more and more resources - they have to do this, because they are competing with others. When things start degrading (soil becomes depleted, or whatever else happens in a particular context), that degradation creates a counterreaction and opens up a regenerative phase needed for saving the region where it occurs. But as soon as the regenerative phase is over, humankind begins a new degradative phase.

According to Mark Whitaker's Ecological Revolution: The Political Origins of Environmental Degradation and the Environmental Origins of Axial Religions; China, Japan, Europe (2010), these cycles are accompanied by a coalition between producing classes and spiritual reformation. This happened in tenth century Europe, when the monks of Cluny started the Peace and Truce of God movement followed by three centuries of growth - this was clearly a regenerative impulse. Another example is The Tokugawa Shogunate from the seventeenth to the nineteenth century Japan, which was a society that lived in balance with its environment for almost three centuries.

\footnotetext{
11 See http://peterturchin.com/. Accessed 8 December 2020.

12 See http://seshatdatabank.info/. Accessed 8 December 2020.

13 See https://wiki.p2pfoundation.net/Sources_of_P2P_Theory\#The_Wave_Pulse_Theory_of_Human_ History. Accessed 8 December 2020.
} 
PJ: How did they manage to achieve such prolonged periods of regeneration?

MB: In regenerative phases, the key aspect of healing is commoning. When you say, 'this is a pool for everybody', and when you protect the pool for the long term, as a commons, then you actually have a healthy basis. But regenerative phases always end when people forget why they protect their commons, and a new elite starts a new degradative cycle. This cycle can clearly be seen in the history of agricultural civilisations, as shown in Peter Turchin's and Sergey A. Nefedov's book, Secular Cycles (2009).

For four centuries, capitalism has managed to maintain the degradative phase through developments in technology and productivity. But now that our reality has become global, there are no more frontiers - nature as a sink and nature as a tap are out of commission. To counter our degradative phase, we need commoning on a local and global scale. Of course, thermodynamic scientists rightly argue that the second law of thermodynamics can be reversed only locally so the environment can also heal only locally. At the same time, there are many issues that remain global. How do you deal with overfishing in international waters? You need a global institution for that. How do you deal with Fukushima-like accidents ${ }^{14}$ ? The radioactive wave does not stop at your border.

This is why we develop the cosmo-local idea: to relocalize the tier of production, and to mutualize it in significant ways, while maintaining global cooperation and global open design depositories. Science and technology then become commons, but locally we have distributed manufacturing and all kinds of new solutions that reinvigorate the territory. This is neither national protectionism nor neoliberal globalization.

PJ: This very much sounds like Ibn Khaldun (1337/2015) and his distinction between circular and linear understanding of history... Richard Barbrook (in Jandrić 2017: Chap 5) has already applied Ibn Khaldun's theory to development of information technology.

MB: Indeed - Ibn Khaldun was one of the first people writing about that. Some aspects of human history are, indeed, circular, and others (such as knowledge growth, societal complexity, etc.) are linear. This results in a spiral development, which, at our moment in history, points downward. This is why biophysical economists talk about the steady state economy. First we need degrowth, which is the objective necessity for diminishing our use of resources, and then we need to move to a steady state.

There is a movement called 'Factor 20 Reduction', covered by John Thackara, which looks into the ways in which we can diminish energy usage in cities by a factor of 20 (Thackara 2015). Can we have a transportation system that uses only 5\% of today's energy? Can we have a habitat system that uses only $5 \%$ of today's energy? The only way to go about this is through mutualization.

\footnotetext{
14 Caused by the 2011 Tōhoku earthquake and tsunami, the Fukushima Daiichi Nuclear Power Plant in Ōkuma, Fukushima Prefecture, Japan, suffered a severe accident followed by extensive radioactive contamination.
} 


\section{The Religious Dream of Transhumanism}

PJ: With Frank Theys, you co-produced the three-part documentary series TechnoCalyps (Theys 2006). 'Technocalyps examines transhumanism. Experts and scientists discuss whether human beings will use discoveries in genetics, robotics, nanotechnology, and artificial intelligence to enhance their bodies and minds beyond their current physical and mental forms.' (IMDb 2021) Part 1: Transhumanism and Posthumanism introduces a bleak picture in which AIs, and artificially improved humans, overtake standard human beings like you and me. And this all happens very quickly - well into our lifetimes. How did you come up with such a scenario?

MB: The documentary was conceived in a paradoxical situation. The director, Frank Theys, was an avowed atheist - but he believed in technology in the sense of a believer who believes in God. I was very 'new age' at that time, but I was also very critical of technology. Because we composed the programme from this weird combination of visions, the documentary lacks a clear political message.

I believe that the need for transcendence is inherent to humanity. When we abandoned religion in the sixteenth century, technology became the new religion. Richard Thompson mapped 64 powers that you can get through yoga. Looking at powers offered by current technology, you can map these powers one on one: bilocation, out-of-body presence ... Transhumanism projects divinity from its core; transhumanists believe that divinity is achievable through technology.

Every scientist has a dream - for instance, to prolong life. Their scientific work advances a little part of that dream, so someone may discover new knowledge about telomeres. Then, transhumanists take all these dreams as if they are already there! That is a completely wrong epistemology and methodology, because transhumanists extrapolate dreams as if these dreams are already realized. Consequently, the transhumanist dream is actually a religious dream. I think this is bad religion, but Frank was a believer in this atheist philosophy. His key argument was that we did not need God, as humanity would achieve all these things by itself using science.

PJ: These days, the Postdigital Science and Education community is doing a lot of research on the ways in which science, which is humanity's most rational achievement, now converges with religion - which, by definition, is based on irrationality (see Reader et al. 2020). Please comment on this dynamic between rationality and irrationality, or in George Ritzer's interpretation of Max Weber (Ritzer et al. 2018), the irrationality of rationality.

MB: The reformational philosopher Herman Dooyeweerd claims that there is no such thing as pure rationality. Rationality is based on axioms, but the axioms themselves cannot be proved. For example, if you say 'we live in a world of subjects and objects', you cannot prove that. That is just an assumption. And then you develop science on that assumption, and a mystic will tell you: 'nothing is separate'. And who can say whether she is right or wrong? There is no way for us to know that. According to Dooyeweerd, we try to be rational, but we also have ground motifs. A lot of our ground motifs are religiously motivated, even though we are not aware of that (Dooyeweerd 2012). 
There are a number of recent books around this thesis. In La Religion industrielle: Monastère, manufacture, usine. Une généalogie de l'entreprise, Pierre Musso (2017) goes into the spirit of capitalism beyond the protestant reformation (Max Weber), and all the way to the Cistercians. In antiquity, work was not a good thing - work was for slaves. A free man had to be able not to work. Being a proletarian movement, the Christians honour work, so Christianity comes with the principle Ora et Labora (work and pray). Back in the day, the Benedictines did not do this very well, so Bernard of Clairvaux, the father of the Cistercian order, says: 'Christianity is not about other people working for us, it is us who need to work. In order to worship God, we have to make our work as efficient as possible.' For the Cistercians, therefore, a monastery is a prayer-maximizing enterprise.

PJ: I never saw work as a centrepiece of religion!

MB: In the Western context, discipline came from the monasteries, before it was exported to the whole of society through the Reformation! Historically, most religious debates are focused on the incarnation. The unique thing about Christianity is the incarnation of God, or the fusion of the divine to all matter. In the early days, this fusion was localised in Christ, in the Renaissance it was localised in nature, and in the eighteenth century it was localised in humanity. Transhumanists really believe in technology, humanity, and so on, but their way of thinking comes directly from Christianity. This moving of incarnation from Christ through nature and humanity to transhumanism is perhaps unconscious, but it comes from a particular mythological worldview. For Musso (2017), and I agree with him, capitalism is a Christian heresy. So yes, we are rational, but our basic axioms are not provable in a rational way, and our rationality exists within very deep unconscious choices that are not made by individuals but by the cultures we live in. You can say 'I'm an atheist' but you are actually a post-Christian, because atheism is a result of Christian history. I would refer here to the work of Dooyeweerd, and his concept of religious ground motives that transpire in modified form in all the people from a particular historical culture (see Basden 2003).

PJ: According to Steve Fuller, in late seventeenth century Europe, 'the difficulties thrown up by the complexity of organisms' have started to be understood

as an 'optimization' problem of matching function to form. This style of thinking first came into fashion ... as a strategy for rationalizing the apparently bad in nature as a good in disguise, a physical limitation as an opportunity for the demonstration of spiritual strength. The trick was to change one's frame of reference from creature to creator-that is, from the naive human observer to 'God's point of view'. The strong Protestant interpretation of humans having been created 'in the image and likeness of God' had become the default position in Christendom, even among many who remained Catholic. (Fuller 2020).

Could we perhaps apply the principles of P2P commoning to reach a better understanding of human nature?

MB: One of the key features of P2P is that the locus of control goes down to the microlevel. Politics used to be dominated by political parties which attracted masses of people; now it is dominated by individuals whose contradictory internal aspects no longer fit in any broad box. We live in an era of 'memetic fragmentation', as 
Peter Limberg and Conor Barnes (2018) have it in their 'The Memetic Tribes Of Culture War 2.0' essay. In knowledge, we went to bits and bytes; in virology, we went to nanotech. In all areas of human activity, we are reaching lower and more fundamental units. Furthermore, peer production demolishes the division of labour and becomes a task allocation method. I think that this is what distributed intelligence is about.

McLuhan noticed that the more we externalize technology, the more the individual weakens. You have a car, so you lose your legs; you have a calculation machine, so you lose the capacity to count. I think this is what happens to humanity: we extend as systems and weaken as individuals. Tribal societies have externalized their limbs using spears and bows; industrial society has externalized the digestive system; knowledge societies externalize our brains and nervous systems by the Internet. I think that transhumanism tries to bring these externalities back inside. I seek solutions in things like liquid feedback, where you can have both distribution and batch processing.

PJ: With this in mind, what is the relationship between P2P principles and (human) evolution?

MB: I would like to mention Kojin Karatani's (2014) framing in The Structure of World History: From Modes of Production to Modes of Exchange. The P2P Foundation's work really started with the discovery of Alan Page Fiske's (1991) relational grammar which distinguishes what he calls communal shareholding, equality matching (the gift economy), authority ranking (distribute and protect), and market pricing. Karatani documents the historical succession of these 'modes of exchange' (not 'modes of production'!), in terms of their relative dominance. And David Ronfeldt (P2P Foundation 2016) sees this in terms of successfully adding new layers of institutions, i.e. first adding Tribes, then adding Institutions, then adding Markets, and finally adding Networks.

Our own theory is largely in accord with Karatani and Fiske, but what we claim specifically, is that we now live in an emerging commons-centric civilisation, with the state and market adapted to the network as the new chaotic attractor. The only human institution that has successfully maintained resources over the long term are the commons! An appropriate governance model for the emerging commonscentric civilisation is what we call super-competent democracy. This is based on a successful mediation of territorial governance, with the emergence of 'translocal' networks of cooperation around open design depositories, which enable 'cosmolocal' problem solving.

PJ: Being so deeply involved with P2P, I somehow assumed that you would incline towards direct democracy... What is super-competent democracy?

MB: Everybody keeps saying that we have a crisis of democracy, but I think that we have a crisis of capitalism. The solution to this crisis does not lie in a better democracy because that is not where the power is; the solution is in distribution of power which has been concentrated in capital. So how does my proposal work in practice?

Capital, nation, and the state are the three institutions that created modernity. But capital has become stronger than the state and nation, so it can no longer be controlled by them. The answer is not necessarily to raise the powers of state and 
nation to counterbalance the power of capital, but to strengthen trans-local and trans-national civic power. NGOs were the first effort in that direction, but I put more faith in networks such as planetary guilds enabled by blockchains. We now see emerging trans-local, permissionless, open collaborative networks, which are very different from hierarchical organizations and corporate models. We can also have functional transnational institutions that are not necessarily international. For example, cities can mutualize their provisioning systems beyond the nation-state by creating 'leagues of cities' that have their own 'protocol cooperatives', i.e., the common knowledge to manage locally adapted cyber-physical infrastructures that dramatically lower the human footprint.

How can we create these planetary cosmo-local institutions? According to Robert Conan Ryan, we now have four dominant magisteria ${ }^{15}$ : (1) Culture, which regulates what you can think and say. (2) Politics, which determines who gets what through the state. (3) Economy or industry, which determines the flows of goods and the distribution of surplus value. (4) Science, which regulates and legitimizes facts. In modern societies, culture, politics, economy, and science are relatively autonomous, but the commons have no voice.

New forms of post-capitalist $\mathrm{P} 2 \mathrm{P}$ accounting give institutional form to the commons, creating the 5th magisterium with its own power and autonomy. For example, thermodynamic accounting proposes the creation of a global Thresholds and Allocations Council. These two entities protect planetary boundaries by imposing limits of fair usage that can be integrated into the accounting and decision-making tools used at every contextual level. This gives institutional power to the protection of nature.

\section{The Time of Monsters}

PJ: Your work extensively refers to cybernetics. What is your take on Paul Cockshott and Allin Cottrell's book Towards a New Socialism (1983), in which they strongly advocate the use of cybernetics for efficient and democratic planning of a complex socialist economy?

MB: I see cybernetics as the capacity for 'orchestrated planning' which was originally a state function, but can now be distributed, used, and enforced by the new Magisteria which we just discussed. For instance, P2P accounting is a bottom-up process which creates a framework that protects nature and gives freedom to agents within that framework. I am not sure whether Paul Cockshott and Allin Cottrell have adapted their views to distributed structures.

PJ: Simone Cicero at Platform Design Toolkit says:

Michel Bauwens believes that because societies are complex adaptive systems, the only way to move towards a new, stable system is through a chaotic transition. The current pandemic shock will serve as a wake-up call,

$\overline{15}$ See https://wiki.p2pfoundation.net/Fifth_Magisterium_of_the_Commons. Accessed 18 January 2021. 
exposing the fallacies of our current systems. What we need forward are strong commons-based institutions that can provide a complimentary, counterbalance to powerful nation-states and existing multilateral organisations. (Cicero 2020).

Please say more about the chaotic part of this transition.

MB: I got this idea from Peter Pogany's book Rethinking the World (2006), which is a history of global capitalism. For Pogany, the world of seventeenth-eighteenth century is a stable, proto-global merchant system that collapses with the French revolution. Around 1815, after 20 years of chaos and Napoleonic wars, the next stabilized system is Smithian capitalism marked by a total domination of capital over labour. Smithian capitalism collapses in WW1, which creates another chaotic period ending after WW2, with the emergence of the social democratic welfare state, which collapses in 2008.

As you can see, the new system cannot emerge before the old system has fully disintegrated; the intermediate period is marked by chaos. Today, we are in another intermediate period. The social democratic welfare state has steadily disintegrated, and an alternative has not stabilized yet. The big question is: Will the new system consist of a new form of capitalism that has integrated P2P and green technologies and so on, or are we looking at something radically different? While it seems that our current system is unable to reset, the enlightened part of the ruling strata are making attempts at fundamentally restructuring the current system in order to survive. This is what the great resets from the World Economic Forum are all about. On the one hand, it is hard to imagine having fully ready, post-corporate structures in place for the transition. On the other hand, it is hard to imagine that structures that are predicated on maximising extraction can solve the problems in necessary ways. So, we 'can't live with them, and we can't live without them'. Solutions like the impact accounting of the Economy of the Common Good may create an outside-in incentive structure, which may encourage these entities to transform their practices while continuing to exist. The challenge is to move to objective 'threshold and allocations' approaches, which take into account the situation of natural resources and the web of life, which creates a binding framework for human decisions. We need to move towards 'system value' approaches, making profit motives dependent on this more encompassing framework.

PJ: Almost a century ago, Antonio Gramsci allegedly said: 'The old world is dying, and the new world struggles to be born; now is the time of monsters' (in Žižek 2010). One of the many crises that we are currently experiencing, and an important source of chaos, is the Covid-19 pandemic (see Jandrić 2020). Based on your recent work in the field (Bauwens 2020), please say more about the coronavirus crisis and the commons.

MB: Drawing from my earlier reply on the crisis of democracy, what we are experiencing at the moment is caused by a failure of the state and the market. Unable to properly fund healthcare, the neoliberal system is simply unable to cope with the pandemic challenge and keeps making the same mistakes. That opens up opportunities for a regenerative response and for commoning. This response can take two forms. One is mutual aid. So we now see a lot of self-organization on a 
local level. The other is normalization of the maker movement. In the early days of the pandemic, makers were able to produce a lot of missing medical equipment such as ventilators, but hospitals were not ready to accept this equipment. The answer to this problem is to create a public commons cooperation pool that would legitimize products and services produced by communities, and place them into existing systems.

PJ: In 'P2P Accounting for Planetary Survival' you write:

Our inspiration comes from the great synthesis provided by Kate Raworth in her book, Doughnut Economics, which graphically presents the great question of our age: can we produce for human needs, without exceeding planetary boundaries?

In our opinion, this requires a fundamental change towards a commons-centric economic system, which can successfully not just conserve, but regenerate human and natural resources. How? By using the 'technosphere': our accumulation of technical and scientific knowledge, but on a new basis of a deep ecological consciousness, in partnership with the other beings on the planet. (P2P Foundation 2020).

Can you please say more about the concept of the technosphere and its applications? MB: The sphere of science and technology, which is basically a service of capital, needs to regain its relative autonomy and be at the service of the commons. I think that the social basis of the commons is primarily in the cognitive class - if you are engaged in cognitive work, you are, by definition, engaged with the commons.

I think that we need to reinvent relationships between humanity, technology, and nature. I think that giving voice to nature is a critical component. In this respect, I find the idea of entangled humanism very important - we need to extend human identity towards this recognition of interdependence. That is an important critique of Elinor Ostrom's (1990) theory of the commons, which still, too often, sees nature as a resource.

\section{The Republic of Internet Letters}

PJ: You are primarily an activist working outside of academic circles. However, your own work, and the work of the P2P Foundation, is very influential in academia. How do you see this dynamic between academic institutions (universities, institutes) and the NGO sector?

MB: People like me fall through the cracks because we operate in interstitial spaces. However, this is not historically unprecedented. Antiquity had academies that disappeared after the collapse of the Roman Empire. The Middle Ages had monasteries that slowly became scholastic universities, and then collapsed during reformation and religious wars in the fifteenth century. Eighteenth century Prussia invented the modern university, and we are now at the end of its era.

Today's universities are no longer places where vibrant knowledge is created, and that brings us to a situation similar to the seventeenth and eighteenth century Republic of Letters. Back in the day, the scholastic university was no longer doing 
its job, so the period is marked with independent scholars who wrote letters to each other. Today, we are in the Republic of Internet Letters.

I was teaching at a university in Thailand for five years, and I never had less time for research and reading. In the neoliberal university, academics spend so much time on obtaining funding and competing against each other that their scholarship seriously suffers. This is why knowledge now flows outside of institutional limits. In Ghent, when I did a study of the urban commons, their connections, and support networks, universities were totally absent - but there was a definitive support by non-university technical schools. However, I think that the university still has a very important role in legitimizing formal knowledge.

One of the things I proposed in Ecuador was to use the university for the legitimization of competencies. Ecuador had a free software policy but they were unable to find computer programmers, because programmers could earn four times more money in the US, so they were not willing to work in their home country. At the same time, Ecuador has thousands of people who can code, but are not recognized because they do not have formal qualifications. So setting up a system which offers some way of recognition, such as open badges and what not, would enable those unrecognized people to program for the government. Unfortunately, my proposal was not accepted.

PJ: Please say more about educational aspects of your work.

MB: In The Art of Memory, Frances Yates (1966/1999) describes that in the Middle Ages, because there was not enough paper, people placed their knowledge in virtual library rooms conceived as castles in their own mind, and because they did that, they would remember everything. As a librarian, I think that a virtual library has an enormous advantage because you remember everything you classify and everything that you cannot classify, makes you alert to innovation.

The P2P Foundation wiki functions as an extension of my brain and the brains of other contributors - it is a tool for organizing our knowledge. That raw material carries its own value which is independent of its creators. Even if my interpretation is totally wrong, the knowledge is still there, so you can interpret it in an entirely different way.

Since 2015, I have published annual syntheses of new knowledge in the wiki. Apart from the wiki, we are very bad at procedural learning. I would like to create an interversity ${ }^{16}$ of the commons; a good example is our forthcoming Commons Economics textbook.

PJ: You are a very successful public intellectual. What does it mean to be a public intellectual in 2021 ?

MB: First, we have open source, which gives us global reach. I am editing this interview in a rain forest in Northern Thailand. Compared to the times of Karl Marx, the idea that you can now be a public intellectual living in a remote place is new. Second, technologies have exposed the collective nature of knowledge. I sometimes say that the P2P Foundation is the collective organic public intellectual in the service of the commons. Third, is the neo-nomadic aspect: if you combine your global intellectual presence with physical travel, it brings about an organic process which plants all these seeds globally.

\footnotetext{
${ }^{16}$ The word 'interversity' is derived from the word 'university' to stress the P2P aspect of knowledge and learning.
} 
Finally, I think that leadership is still very important. Individuals can embody value systems - especially if they 'walk their talk'. Before 2014, I had no institutional funding. I was without any income for seven years, so I had to beg for donations on Facebook. Such honesty gets people's trust, which is paramount for any public intellectual.

PJ: Which seed forms of today do you consider to be the most relevant for the society of tomorrow?

MB: I am very focused on financial autonomy. I used to be a Marxist and I am still very interested in who captures the surplus. That is what class is about... I am not against volunteering, but I think that the primary focus of our work should be to create livelihoods. The commons need to prove that they can sustain themselves, so I look a lot at these projects and learn about livelihoods, ownership, and governance. How do these projects succeed in being inclusive and efficient at the same time? The next step in that direction, I think, is distributed property such as community land trusts.

I oppose the vision that the commons cannot have a relationship with the market because that condemns the commons to the domain of volunteers. I want commons where people can make a living, buy a house, educate their children. At the moment, the commons is a marginal seed form, and that is okay. But the commons should not remain an exception - it should become the norm. That makes the commons very political. How do we create regulatory frameworks that will achieve the mainstreaming of the commons?

Acknowledgements We are thankful to Alison MacKenzie for her valuable comments and suggestions on earlier versions of this article.

\section{References}

Basden, P. (2003). Dooyeweerd's theory of ground motives and religious presuppositions. http://www. dooy.info/ground.motives.html. Accessed 18 January 2021.

Bauwens, M. (2005). P2P and human evolution. https://wiki.p2pfoundation.net/P2P_and_Human_ Evolution. Accessed 18 January 2021.

Bauwens, M. (2020). Corona and the commons. https://blog.p2pfoundation.net/corona-and-thecommons/2020/04/03. Accessed 18 January 2021.

Bauwens, M., \& Kostakis, V. (2014). From the communism of capital to capital for the commons: Towards an open co-operativism. TripleC, 12(1), 356-361. https://doi.org/10.31269/triplec.v12i1.561.

Bauwens, M., \& Lievens, J. (2013). De Wereld Redden, met peer to peer naareen postkapitalistischesamenleving. Antwerpen: Houtekiet.

Bauwens, M., \& Pazaitis, A. (2020). P2P Accounting for Planetary Survival: Towards a P2P Infrastructure for a Socially-Just Circular Society. Amsterdam: P2P Foundation, Guerrilla Foundation and Schoepflin Foundation. http://commonstransition.org/wp-content/uploads/2019/09/AccountingForPlanetarySurvival_ defx-2.pdf. Accessed 18 January 2021.

Cicero, S. (2020). Commons-based peer production at the edge of a chaotic transition-With Michel Bauwens. Boundaryless Conversations Podcast \#6, 21 April. https://stories.platformdesigntoolkit. com/commons-based-peer-production-at-the-edge-of-a-chaotic-transition-6-462286840af3. Accessed 18 January 2021.

Cockshott, W. P., \& Cottrell, A. (1983). Towards a new socialism. Nottingham: Russell Press.

Dean, J., Medak, T., \& Jandrić, P. (2019). Embrace the antagonism, build the Party! The new communist horizon in and against communicative capitalism. Postdigital Science and Education, 1(1), 218-235. https://doi.org/10.1007/s42438-018-0006-7.

Dooyeweerd, H. (2012). Roots of western culture. New York: Paideia Press. 
Fiske, A. P. (1991). Structures of social life: The four elementary forms of human relations: Communal sharing, authority ranking, equality matching, market pricing. New York: Free Press.

Fuller, S. (2020). Schrödinger's 'What Is Life?' As Postdigital Prophecy. Postdigital Science and Education. https://doi.org/10.1007/s42438-020-00149-w.

IBM (2019). Blockchain basics: Introduction to distributed ledgers. 1 June. https://developer.ibm.com/tutorials/ cl-blockchain-basics-intro-bluemix-trs/. Accessed 7 December 2020.

Ibn Khaldun, M. (1337/2015). Muqaddimah. http://www.muslimphilosophy.com/ik/Muqaddimah/. Accessed 18 January 2021.

IMDb (2021). TechnoCalyps. https://www.imdb.com/title/tt0899298/plotsummary?ref_=tt_ov_pl. Accessed 18 January 2021.

Jandrić, P. (2017). Learning in the age of digital reason. Rotterdam: Sense.

Jandrić, P. (2020). Postdigital research in the time of Covid-19. Postdigital Science and Education, 2(2), 233238. https://doi.org/10.1007/s42438-020-00113-8.

Jandrić, P., Ryberg, T., Knox, J., Lacković, N., Hayes, S., Suoranta, J., et al. (2019). Postdigital dialogue. Postdigital. Science and Education, 1(1), 163-189. https://doi.org/10.1007/s42438-018-0011-x.

Karatani, K. (2014). The structure of world history: From modes of production to modes of exchange. Durham, NC: Duke University Press.

Kleiner, D. (2010). The Telekommunist Manifesto. Amsterdam: Institute of Network Cultures.

Kostakis, V., \& Bauwens, M. (2014). Network society and future scenarios for a collaborative economy. New York: Palgrave Macmillan.

Limberg, P. N., \& Barnes, C. (2018). The memetic tribes of culture war 2.0'. Medium, 14 September. https://medium.com/s/world-wide-wtf/memetic-tribes-and-culture-war-2-0-14705c43f6bb. Accessed 18 January 2021.

Lovink, G., \& Rossiter, N. (2018). Organization after social media. Colchester, New York, Point Watson: Minor Compositions.

Musso, P. (2017). La Religion industrielle: Monastère, manufacture, usine. Une généalogie de l'entreprise. Paris: Fayard.

Ostrom, E. (1990). Governing the commons: The evolution of institutions for collective action. Cambridge, UK: Cambridge University Press.

P2P Foundation (2016). David Ronfeldt on the history and evolution of the Chamber of the Commons. https://blog.p2pfoundation.net/david-ronfeldt-history-evolution-chamber-commons/2016/04. Accessed 18 January 2021.

P2P Foundation (2020). P2P accounting for planetary survival. https://commonstransition.org/p2paccounting-for-planetary-survival/. Accessed 18 January 2021.

Peters, M. A., Besley, T., Jandrić, P., \& Zhu, X. (Eds.). (2020). Knowledge socialism. The rise of peer production: Collegiality, collaboration, and collective intelligence. Singapore: Springer.

Pogany, P. (2006). Rethinking the world. Lincoln, NE: Shenandoah Valley Research Press and iUniverse.

Polanyi, K. (1944/2001). The great transformation: The political and economic origins of our time. Boston, MA: Beacon.

Ralston, S. J. (2019). Postdigital prospects for blockchain-disrupted higher education: beyond the theater, memes and marketing hype. Postdigital Science and Education, 2(2), 280-288. https://doi. org/10.1007/s42438-019-00091-6.

Reader, J., Jandrić, P., Peters, M. A., Barnett, R., Garbowski, M., Lipińska, V., et al. (2020). Enchantmentdisenchantment-re-enchantment: Postdigital relationships between science, philosophy, and religion. Postdigital Science and Education. https://doi.org/10.1007/s42438-020-00133-4.

Ritzer, G., Jandrić, P., \& Hayes, S. (2018). Prosumer capitalism and its machines. Open Review of Educational Research, 5(1), 113-129. https://doi.org/10.1080/23265507.2018.1546124.

Thackara, J. (2015). How to thrive in the next economy: Designing tomorrow's world today. London: Thames \& Hudson.

Theys, F. (2006). TechnoCalyps [film]. Ghent: Itinera.

Turchin, P., \& Nefedov, S. A. (2009). Secular cycles. Princeton, NJ: Princeton University Press.

Whitaker, M. D. (2010). Ecological revolution: The political origins of environmental degradation and the environmental origins of axial religions; China, Japan, Europe. Saarbrücken: LAP.

Yates, F. A. (1966/1999). The Art of Memory. London and New York: Routledge.

Žižek, S. (2010). A permanent economic emergency. New Left Review, 64, 85-95. 